\title{
Kadınların Sesinden Kamusal Alanda Toplumsal Cinsiyet Söylemi: Türkiye'de 8 Mart Kutlamaları
}

\author{
Nagehan Vanlığlu Yazıc1 ${ }^{1}$ \\ ORCID: 0000-0001-5597-2278
}

Öz

1960'lardan bu yana mekân ve toplumsal cinsiyet teorileri, mekânm sosyal bir üretim olduğu anlayışının kabulü ile ortak bir paydada çalışılmaya başlanmıştır. Mekânın toplumsal etkilerin bir ürünü olarak gözlemlendiği düşünüldüğünde, toplumsal cinsiyet ile mekân arasındaki ilişkinin toplumsal cinsiyet söyleminden etkilendiği ve bu söylemin etkisi altında şekillendiği ifade edilebilir. Bu çalışma toplumsal cinsiyet söyleminin ana nesnelerinden biri olan kadına odaklanmıştır. Bunun için çalışma öncelikle, mekân ve toplumsal cinsiyet çalışmalarının en çok değinilen konularından biri olan kamusal ve özel mekân ayrmmına odaklanarak, teorik bir çerçeve oluşturmuştur. Ardından örneklemini açıklamak üzere Türkiye'de kadın hareketine ve 8 Mart yürüyüş̧lerine değinerek, örnek çalışmasını 8 Mart 2020 tarihli kadınlar günü kutlamaları olarak belirlemiş ve incelemiştir. Özetle, çalışma kamusal mekânın sosyal bir üretim olduğu anlayışı ile kadın ve kamusal mekân arasındaki ilişkiye, söylem analizi temellendirmesi ile Türkiye'de gerçekleşen 8 Mart kutlamalarındaki slogan ve pankartlara odaklanarak, bu problematik ilişkiyi, kadınların kendi sesleriyle anlamlandırmaya çalışır.

Anahtar Kelimeler: Kamusal Mekân, Toplumsal Cinsiyet, Feminist Eleştirel Söylem Analizi.

\footnotetext{
1 Öğr. Gör., Medipol Üniversitesi, E-mail: vanlioglunagehan@gmail.com idealkent (c) Kent Araştırmaları Dergisi (Journal of Urban Studies) http://idealkentdergisi.com
} 


\title{
Gender Discourse in the Public Sphere through the Voice of Women: 8 March celebrations in Turkey
}

\author{
Nagehan Vanlığlu Yazıc1 ${ }^{2}$ \\ ORCID: 0000-0001-5597-2278
}

\begin{abstract}
Since the 1960s, space, and gender theories have begun to work on common ground with the acceptance of the understanding that space is a social production. Considering that space is observed as a product of social impressions, it can be stated that the relationship between gender and space is affected by gender discourse, and it is shaped under the influence of this specific discourse. This study focuses on women as one of the main objects of gender discourse. Therefore, it establishes a theoretical framework, focusing primarily on the distinction between public and private space, which is one of the most discussed issues of space and gender studies. To better describe its case study, the study discusses the women's movement in Turkey and March 8th celebrations. After that, the study examines March 8th, 2020, as its case study. In summary, the study focuses on the relationship between women and public space with the understanding that public space is a social production based on discourse analysis and by addressing women's slogans and banners on March 8th celebrations that took place in Turkey and tries to make sense of this problematic relationship by women's own voices on public space.
\end{abstract}

Keywords: Public Space, Gender, Feminist Critical Discourse Analysis.

2 Lecturer, Medipol University, E-mail: vanlioglunagehan@gmail.com

idealkent (c) Kent Araştırmaları Dergisi (Journal of Urban Studies)

http://idealkentdergisi.com

Geliş Tarihi Received Date: 01.06.2020 Kabul Tarihi Accepted Date: 09.12.2020 


\section{Giriş}

Mekân ile cinsiyet teorisini birleştiren çalışmalar ilk olarak 1960'lar sonrası, o yilların değişken atmosferi ile gelen sosyal kabullerdeki devinim ile daha önce değinilmemiş konuların toplum tartışmalarında kendine yer bulması sonucu ortaya çıkmıştır. 1960'lar daha önce hiç tartışılmamış veya nadiren üzerinden geçilmiş konuların ve var olan normlara farklı anlamlar bulma/kazandırma çalışmalarının gündeme geldiği, bu durumun toplumun büyük bir kısmı tarafından ötekileştirilen grupların sosyal alanda ses bulmasını sağladığ1 yıllardır. Böyle bir toplumsal ortamda, kadın hakları, öğrenci hakları ve savaş karşıtı gruplar için tartışmalar da yoğunluk kazanmıştır. Beklenebileceği gibi, 60'ların farklılıkları vurguladığı bu atmosfer içerisinde ötekinin sesi üniversitelerde kayda değer bir şekilde yankılanmış; yeni bölümler kurulmuş ve ötekinin meseleleriyle ilgili çalışmalar meşrulaştırılmıştır. Toplumsal cinsiyet tartışmaları bu yıllarda akademi tarafından kabul edilmiş ve alan çalışmaları yürütülmüştür.

Bahsedilen bağlamda mekân da önemli tartışma konularından biri olmuştur. Coğrafya bilimciler bu konu üzerinde tartışarak, mekânın genişleyen ve değişen anlamlarını bulmaya odaklanmıştır. Seçkin bir filozof ve sosyolog olan Henri Lefebvre (1991, s.26) "(Sosyal) mekân (sosyal) bir üretimdir" savını ortaya koymuş ve böylelikle kendinden sonra pek çok önemli sosyolog, coğrafya bilimci, mimar ve hatta dilbilimcinin yürüyeceği bir güzergâh tariflemiştir. Mekânın "sosyal bir üretim" olduğu anlayışı ile birlikte toplumsal cinsiyet ve mekân arasında kaçınılmaz bir ilişki olduğu da kabul edilmiştir. Böylece bu ilişkinin problemli yapısına akademik ve sosyal bir perspektif ile odaklanmak mümkün olmuştur. Toplumsal cinsiyet mekânsal tartışmalarda güçlü bir özne olarak ortaya çıkmıştır. Diana Agrest (1991, s.32) ideolojinin toplumsal bir üretim olduğunu, dolayısı ile mimari dâhil tüm kültürel üretimin belirli bir toplumsal yapının parçası olarak, ideolojinin üretim sürecini ifade ettiğini belirtmiştir. Dolayısı ile toplumsal anlayışın belirlenmesinde mimari, toplumsal cinsiyet ile beraber önemli ve kesin bir rol oynamaktadır.

Bu noktada mimarinin bir anlamda toplumu yansıtan bir araç, bir ifade yöntemi hatta bir dil olduğunu ve toplumsal söylemin etkisinde bir özne olarak var olduğunu söylemek yanlış olmaz. Foucault (1972)’ya göre söylemler "nesnelerini" kavramsal olarak, ifadelerin dolaşımı yoluyla üretir. Söylem; düşünce, inançlar, yargılar, değerler, semboller, kelimeler, harfler, kurumlar, normlar ve geleneklerden oluşan, tüm dünyayı ve insanları şekillendiren, zıt 
kelimelerle ifade edildiğinde dahi bile göz ardı edilemeyen canlı bir organizmadır. Yani söylem, sosyal yapıyı kuran ve bu yapı içerisinde biçimlenen yadsınmaz bir etkidir. Mekânın toplumsal etkilerin bir ürünü olarak gözlemlendiği düşünüldüğünde, toplumsal cinsiyet ile mekân arasındaki ilişkinin cinsiyet söylemi gibi belirli bir söylemden etkilendiği ve şekillendiği ifade edilebilir. Bu çalışma bu geniş konunun ana nesnelerinden biri olarak 'kadina' odaklanmaktadır.

Agrest (1991, s.173)'e göre sistemler yalnızca içindekilerle değil, dışladıkları ile de tanımlanır. İçerme ve dışarıda tutma durumu aynı yapıyı oluşturan parçalardır. Kadın ve kadın vücudu mimaride baskı altında tutulan, eksik ve dışlanan bir özne konumundadır. Bu göz ardı ediş ve dışlama toplumsal cinsiyet meselesini mimari alanda sorunlu olarak işaretlemektedir. Toplumsal cinsiyet sorunu yerleşik sosyal normların tam ortasındadır ve mimariböylece ataerkil önyargılara hizmet ederek, bir anlamda bu normları mekânda sembolik olarak somutlamaktadır. Bu durum kadınları ötekileştirmektedir. Böylece ötekileştirilerek, dış bir grup oluşturan kadınlar kent hakkından yoksun olurlar. Lefebvre, şehir deneyimini günlük yaşama bağlar ve bu terimi günlük rutinlerin ötesinde kullanır; "otantik deneyimin, benliğin, bedenin ve başkalarıyla etkileşimin yeri" olarak belirtir (Shileds, 1999). Lefebvre'nin kent hakkı üzerine fikirlerini belirttiği yazısında David Harvey (2008, s. 270), Robert Park'ın şehir tanımından alıntı yapar;

İnsanın tutarlı ve bir bütün halinde, en büyük başarısı içinde yaşadığı dünyayı arzuladığınca yeniden yaratmaya yönelik çabasıdır. Ancak, eğer şehir insanın yarattığı dünyaysa, o zaman yaşamak için mahkûm olduğu dünya da orasıdır. Böylece, dolaylı olarak ve görevinin doğası hakkında net bir hissi olmadan, şehrin yaratımında kendini yaratır

Dolayısıyla şehir ile bireyler arasındaki ilişki birbirini etkileyen ve oluşturan faktörler olarak anlaşılmalıdır. Her birey için şehir hakkı elde edilmek isteniyorsa, cinsiyet meselesi büyük bir endişe olarak kabul edilmelidir. Dolayısı ile feminist hareketin dile getirdikleri, kadının şehirdeki hakkı ve varlığı açısından kritiktir.

Bahsedildiği üzere Lefebvre (1991) mekânın sosyal bir anlayış ile kavranması gerekliliğini ortaya koymuş ve ardından Marksist yaklaşım düşünürleri Edward Soja (1989) ve David Harvey (2008) ile bu anlayış devam etmiştir. Ancak toplumsal ilişkilerin detaylıca ele alındığı bu mekân analizlerinde, toplumsal cinsiyet konusu görmezden gelinmiş ve Feminist coğrafyacıların mekân ile kadın arasında bağlantı kurarken ilk eleştirileri de disipline egemen olan erkek coğrafyacıların oluşturduğu eril coğrafya bilgisi olmuştur. 
(Bondi ve Davidson, 2003; McDowell, 1992). Böylece coğrafya bilgi ve disiplinine kadın deneyimini taşıma gayretinde olan feminist coğrafyacılar, 1980'den 1990'lara kadar cinsiyetlere dayalı mekânsal deneyim farklılıklarını çalışarak, disiplindeki konumlarını güçlendirmiş, 1990 sonrasında ise coğrafyanın ataerkil inşası ve toplumsal cinsiyetlerin mekânsal üretimi üzerinde durmuştur (McDowell, 1993).

Dolayısı ile bu çalışma feminist coğrafyacıların izinde, kamusal mekânın sosyal bir üretim olduğu anlayışı ile kadın ve kamusal mekân arasındaki ilişkiye, söylem analizi temellendirmesi ile odaklanır ve Türkiye'de 8 Mart yürüyüsslerinde kadınların kendi sesleri ile mekâna dair söyledikleri slogan ve ürettikleri pankartları örneklem olarak alır.

\section{Kadın ve Kamusal Mekân: İkiliğin İzinde}

Kamusal mekânın cinsiyet ilişkileri ve toplumsal rol kabullerinde etkisini daha iyi anlayabilmek için, öncelikle kamusal alan kavramına odaklanmak gereklidir. "Kamusallık kavramı, topluma ait olmak kadar devlete dair olmayı da ima eden anlam ikiliğini sıklıkla mekâna, özellikle de devlet eliyle tahsis ve tanzim edilmiş olana yansitır" (Basa, 2018). Dolayısı ile kamusal alan doğası gereği içerisinde bir ikilik barındırır. Buradan hareketle, kitleleri ifade eden "kamu" kelimesinin toplumun tüm kesimlerini temsil etmede çoğunlukla yetersiz kaldığını söylemek mümkün olacaktır. Ne yazık ki, erişilebilirlik çağrışımına rağmen, kamusal alan bazen, belirli grupların veya azınlıkların haklarını ve erişimlerini örtük biçimde sınırlayabilir. Bu nedenle ataerkinin inşası altında olan bir toplumsal mekânın kadını dışlıyor olması da şaşırtıcı değildir.

Feminist coğrafya içerisinde en çok müzakere edilen konulardan biri, kamusal ve özel alan arasındaki ayrımdır. Jane Rendell; Lefebvre'nin toplumsal olarak üretilmiş sosyal mekân teorisinin, bu ayrışmanın eleştirisi için bir yol açtı̆̆ını vurgular. Rendell (2007, s.103) bu ayrışma ile Lefebvre' in üçlemesi olan "alģlanan, tasarlanan ve yaşanan mekân" 1 şu şekilde ilişkilendirir;

Toplumsal cinsiyetli mekânın en yaygın temsili, "ayrı küreler (separate spheres)" paradigması, egemen bir kamusal erkek üretim âleminden (şehir) ve ikincil bir özel dişi üreme alanından (ev) oluşan muhalif ve hiyerarşik bir sistemdir. Şehri evden, kamuyu özelden, üretimi tekrar üretimden ve erkeği kadından ayıran bu ideolojinin kökenleri hem ataerkil hem de kapitalisttir. Ancak, bir ideoloji olarak, tüm kentsel sakinlerin yaşanmış tüm deneyimlerini 
tanımlamaz. Bu durum, feministler için problematiktir, çünkü bu ikili hiyerarşide biyolojik cinsiyet, toplumsal cinsiyet ve mekân hakkındaki varsayımlar sürekli olarak yeniden üretilmektedir.

Tarihsel olarak, kamusal ve özel mekân ayrımı, batı orta sınıf günlük yaşam koşullarının doğasında bulunan idealize edilmiş alanlar (ayrı küreler) fikriyle başlamıştır. İş ve ev yaşamının bölünmesiyle, banliyöler ve ticari merkez olarak şehirlerin gelişmesi, çalışma alanının erkek ile ilişkilendirilmesi bu ayrışmaya yol açmıştır. Feminist coğrafyanın izinde, kamusal ve özel alan ilişkisinin sadece fiziksel bir görüngü değil, aynı zamanda ideolojik ve politik bir konu olarak da düşünülmesi gerektiğini söylemek mümkündür. Nancy Duncan (1996, s.128)'a göre;

Kamu ve özel arasındaki ayrım, siyaset felsefesi, hukuk, popüler söylem ve tekrarlayan mekânsal yapılanma uygulamalarına dayanmaktadır. Bu uygulamalar, ağırlıklı olarak kamusal alanda yer aldığı iddia edilen, dağınık siyasi alandan özel, yerli, somutlaşmış bir faaliyet alanını ayırır ve izole eder. Kamu/özel ikilemi (hem siyasi hem de mekânsal boyutta), geleneksel ataerkil ve heterosist güç yapılarını koruyan cinsiyet ve cinsel farklılı̆̆ inşa etmek, kontrol etmek, disiplin etmek, sınırlamak, dışlamak ve bastırmak için sıklıkla kullanilır.

Buna ek olarak, feminist teori bu tartışma yoluyla kadınlarla erkekler arasındaki çelişkili ilişkiyi ele almaktadır. Liz Bondi (1998) kamusal ve özel mekân kavramının feminist çalışmalarda bu denli odaklanılan, ilgilenilen bir alan olmasını bu ikiliğin kadın ve erkek arasındaki ayrıştırma ve ayrımlarla yakından, fakat problematik bir şekilde ilişkili olmasına bağlar.

Judith Butler (1988), toplumsal cinsiyet fenomeninin, sosyal ortamları belirleyen (sosyal) koşulların bir sonucu olarak, eylemler ve vücut performansları tarafından yaratıldığını iddia eder. Kamusal ile özel mekân ayrımı, her iki cinsiyeti kamusal alanda ataerki tarafından belirlenmiş sınırlar içerisinde belirli rolleri sergilemeye iter. Dolayısı ile cinsiyetli mekân, kalıplaşmış cinsiyet önyargılarının tekrar üretiminde ciddi bir aktördür. Bu üretim ilişkisi, kadının ataerkil temsilleri ile kamusal mekânda desteklenir. Toplumsal cinsiyetli bir şehirde kadınlar özel alanla, evle, annelikle, muhafazakârlıkla ilişkili; erkekler ise kamusal alanla, çalışma alanı ve emekle ilişkili olarak görülmektedir. Kadınları bu konuma yerleştirmek kaçınılmaz olarak diğer alanlarda ayrımcllı̆a neden olmaktadır. Kadınlar evde stereotipik olarak belirlenmiş görevler ile sarılmıştır. Toplumsal cinsiyet norm ve performansları onları bakım, temizlik, ev düzenleme sorumluluğuna bağlar. Bu durum kendileri ve 
çevreleri hakkında karar verme haklarını ortadan kaldırır. Dolayısıyla, kadınlarla ilgili olduğu söylenen ev aslında ataerkil bir sistemde erkeğe hizmet eder ve erkeklere aittir.

Kamusal mekân, özellikle politik ve ideolojik fikirlerin çarpışttğı alan olarak anlaşılabilir. Böylece kamu meseleleri, çalışma firsatları, faaliyetler hakkında konuşma fırsatı ile birlikte, kamuoyu içinde anlaşılmama ve kabul hakkını sunar. Hannah Arendt (2012), insan varoluşunun başlıca ve ayırt edici yapısını eylem ve pratik/politik yaşam alanı olarak tanımlar. Arendt'e göre, kamusal alan eylemin alanı iken özel alan iş ve emeğin alanıdır. Bu iş ve emek etkinlikleri kadının siyaset alanından, zorunluluk alanına hapsi ile sonuçlanmış, erkeğe ise bu etkinlikler dışında özgürlük ve siyaset alanı sunmuştur. (Arendt, 2012, s.68). Dolayısı ile feminist hareketin kamusal alanda hak talebi özgürlük yoksunluğundan doğmuş saf politik bir eylem niteliği taşır.

\section{Yöntem}

Bu çalışmada Türkiye'de kadınlar günü kutlamaları içerisinde, kadınların sloganlar ve pankartları incelenerek, kamusal alan için tanım, hak ve talepleri kendi söylemleri üzerinden ele alınacaktır. Bunu yaparken feminist eleştirel söylem analizi kullanılacaktır. Lazar (2007) eleştirel söylem analizini dil ile sürdürülen eşitsiz sosyal düzene, sosyal dönüşüm ve özgürleşme hedefli eleştirel bir bakış olarak tanımlar. Feminist eleştirel söylem analizinin amacını ise şu şekilde belirtir; "erkeği sistematik bir biçimde sosyal bir grup olarak ayrıcalıklı kılan ve kadını sosyal bir grup olarak dışlayan, güçsüzleştiren ve dezavantajlı kılan güç ilişkilerini yani ataerkil sosyal düzeni sürdüren söylemleri eleştirmektir" (Lazar, 2007, s.5).

Foucault' a göre söylem, belirli bir gerçeklik düzenini ve (düzen) içinde belirli özne konumları üreten ve düzenleyen bir dizi ilgili ifadeyi tanımlar (1972, s.107). Söylem, bir anlamda bilme yöntemimizi, sistem içerisinde kimlikleri, kişi konumlarını ve kişilerin ilişkileri kurma yollarını belirler (Lazar, 2007, s.143).

Bu anlamda çalışma, söylem analizini kadınların kamusal alanda haklı̈̈zgürlük arayışlarını ifade şekillerini ele alır ve irdeler. 8 Mart 2020 kadınlar yürüyüşü eylemi bu anlamda örnek olarak belirlenmiştir. Fotoğraflara twitter ağırlıklı olmak üzere kadın derneklerinin (Toplumsal Eşitlik Platformu: @TEPlatformu, 8MartFeministYürüyüş: @8martyuruyus) twitter hesaplarından, sosyal medya aracılığı ile ulaşılmıştır. Orijinal içeriklere linkler üzerinden ulaşılabilmektedir. 
Çalışma mekân ve toplumsal cinsiyet teorilerinin ortasında, söylem analizi ile konumlanırken, öncelikle Türkiye' deki hareket ve 8 Mart yürüyüşüne bakacak, daha sonra bir önceki bölümde kavramsallaştırdığı kamusal ve özel mekân ikiliğine atıfta bulunarak, 8 Mart 2020 tarihli kadınlar günü kutlama ve eylemlerini örneklem olarak ele alacaktır.

\section{Türkiye'de Kadın Hareketi ve 8 Mart Kadınlar Günü}

Yürüyüşün analizine geçmeden önce Türkiye'de kadın hareketine ve 8 Mart yürüyüşlerinin tarihine bakmak anlamlı olacaktır. Türkiye'de feminist hareketin bağlamı Avrupa ülkelerine benzer bir arka plana sahip değildir; Ortadoğu ülkeleri arasında ise yine farklı ve önemli bir yer tutmaktadır. Deniz Kandiyoti (1987, s.320) “Ortadoğu ülkeleri arasında Türkiye, kadınların özgürleşmesi sorununu erkenden, açıkça ve kapsamlı bir şekilde ele alan bir cumhuriyet olarak seçilebilir" der. Batı feminist teorisi, İslam toplumlarını anlama ve analiz etmede eksik kalmıştır. Bu eksiklik Türkiye'deki çalışmaları, tüm feminist çalışmalar arasında, dini ve laik söylemler arasında kaçınılmaz bir tartışmayı da ele alan özel bir yerde konumlandırır.

Ülkenin kendine özgü koşulları ve süreçleri ile ilgili olarak, Türkiye'deki hareketin gelişimi nispeten benzersiz bir şekilde gerçekleşmiştir. Türkiye'deki hareketin ilk kıvılcımlarının Osmanlı İmparatorluğu'na kadar sürülebilmesi mümkün iken, ilk feminizm dalgası ve hareketin asıl başlangıcı 20. yüzyılın başlarında Cumhuriyet dönemi ve dönemin kadın örgütleriyle gerçekleşmiştir. Bu örgütler kadınların sivil ve siyasi haklarına odaklanmıştır. Kemalizm'in bir ideali olarak, Batılılaşmış bir toplum olmak, tüm vatandaşlar arasında toplumsal cinsiyet konusunda yasal eşitlik sağlayacak reformlara ihtiyaç duyulmasına neden olmuştur. 1926'da İsviçre Medeni Kanunu'nun etkisiyle Türk Medeni Kanunu oluşturulmuş ve yeni hükümet tarafından kadınlara birtakım haklar verilmiştir (Vanlığlu Yazıcı, 2019).

1940 ve 50'lere doğru kırsal alandaki kadın durumunu araştırmaya yönelen hareket, 1960'lar ile beraber yeni kavram tartışmaları ile genişlemiştir. Bu yıllarda ilk defa aile planlaması ve doğurganlık gibi konular üzerinde durulmuştur. Eğitim ise modernleşmenin en önemli unsurlarından biri olarak görüldüğünden, kadınların eğitim hakları da bu yıllarda öncelikli olarak tartışılmıştır (Arat, 1993).

1980'lerde askeri darbeden sonra sosyal yapıdaki dalgalanmalar, daha sonra aşırı veya marjinal olarak görülen, feminizm ve kadın hakları da dahil olmak üzere fikirlerin geliştirilmesi için ilginç bir fırsat yaratmıştır. Özellikle 
askeri darbeden sonra ekonomik kriz toplumdaki rolleri ve dolayısı ile kadınların rolündeki değişiklikleri tetiklemiştir. Bu dönemde kadınların çalışma hayatına girmeleri feminist harekete hız kazandırmıştır. Dolayısı ile evden kamusal alana taşan kadının İkinci Dalga Kadın Hareketinin devindirici iç dinamizmini oluşturduğu söylenebilir (Karagöz, 2008).

1980'ler, Türkiye'nin feminist tarihinde, kadın meselesinin feminist bir perspektiften ilk kez ele alındığı ve feminist önceliklerin ışığında biçimlendiği dönemdir. Aynı dönemde Batı'da hızlanan hareket, Türkiye'ye de uzanmış, kadınların cinselliği ve aile içi şiddet gibi göz ardı edilen konular tartışılmaya başlanmıştır. Sokakta var oluşu da güçlenen hareket bu yıllarda üniversitelere de uzanmıştır. 1980'lerin sosyo-politik koşullarından sonra, 1990'larda akademideki kadın hareketinin etkisi artmıs, konu üzerine yayınlarının sayısı hızla yükselmiştir. Ayrıca bu dönemde feminist hareket, metropollerden daha küçük şehirlere yayılmıştır. 1990'ların bir başka özelliği, 80'lerde feminist hareketin parçası olmayan kadınların harekete ilgi duyması ve çeşitli feminist talepler düzenlemesidir. Liberal, İslamcı, Sosyalist, Marksist, Radikal gibi farklı feminizmlerin varlığı 1990'larda ortaya çıkmaya başlamıştır (Kara, 2006).

2000'lerden sonra, ise feminist hareketin tarifi zorlaşmıştır, hareket kendi içerisinde çok daha karmaşık hale gelmiş ve çeşitlenmiştir. Feminist hareketin İstanbul merkezli yapısı büyük ölçüde parçalanmıştır. Bu çeşitlilik sadece kimlik çeşitliliğini değil, aynı zamanda sınıf ve siyasi görüş ayrımlarını da içerir. LGBTİ+ örgütleri güçlenmiş, dinamizm kazanmış ve feminizm içerisinde ciddi bir faktör haline gelmiştir. 2000'li yıllardan sonra ise dijital alanda kadın sorunu feminist tarihte yeni bir sayfa olarak ortaya çıkmıştır (Kuriş, 2015).

Dünya kadınlar günü ilk olarak 1911 tarihinde kutlanmıştır ve o günden beri yüzyıldan fazla bir süredir kutlanmaktadır. Gün herhangi bir ülkeye, gruba veya kuruluşa özgü değildir ve dünyanın her yerinde kolektif olarak tüm gruplarca kutlanmaktadır. Türkiye'de ise 8 Mart toplantısı ilk kez 1921 yılında düzenlenmiş ve yine bu yıl "Emekçi Kadınlar Günü" olarak kutlanmış ve 1975 yılında Beria Onger önderliğinde kurulan İlerici Kadınlar Derneği tarafından ilk kez sokaklara taşınmıştır (Mimarlar Odası İstanbul Büyükkent Şubesi, 2013). 70'li yıllarda yaygınlaşan gün, 1980-84 yılları arasında kutlanmamış ancak 1984'ten itibaren kadınların kazandıkları hakları hatırlamak ve kazanılması gerekenleri topluma hatırlatmak için kutlanılmaya devam edilmiştir. 


\section{Örnek Çalışma: Kadınların Sesinden Kent Üzerine, 8 Mart 2020}

8 Mart 2020 tüm dünya ile birlikte Türkiye'de de yürüyüşlerle kutlanmış, özellikle İstanbul Taksim'de gelenekselleşmiş Feminist Gece Yürüyüşü, İstanbul Valiliğinin yasak kararına ve polis ablukasına rağmen büyük bir kalabalıkla gerçekleşmiştir. Kadınlar şiddete ve eşitsizliğe karşı seslerini duyurmuştur. Çalışma özellikle kamusal alan dışına itilen kadının durumunu ve haklı talebini, kadınların kendi söylemleri aracılığı ile incelemeyi amaçlar.

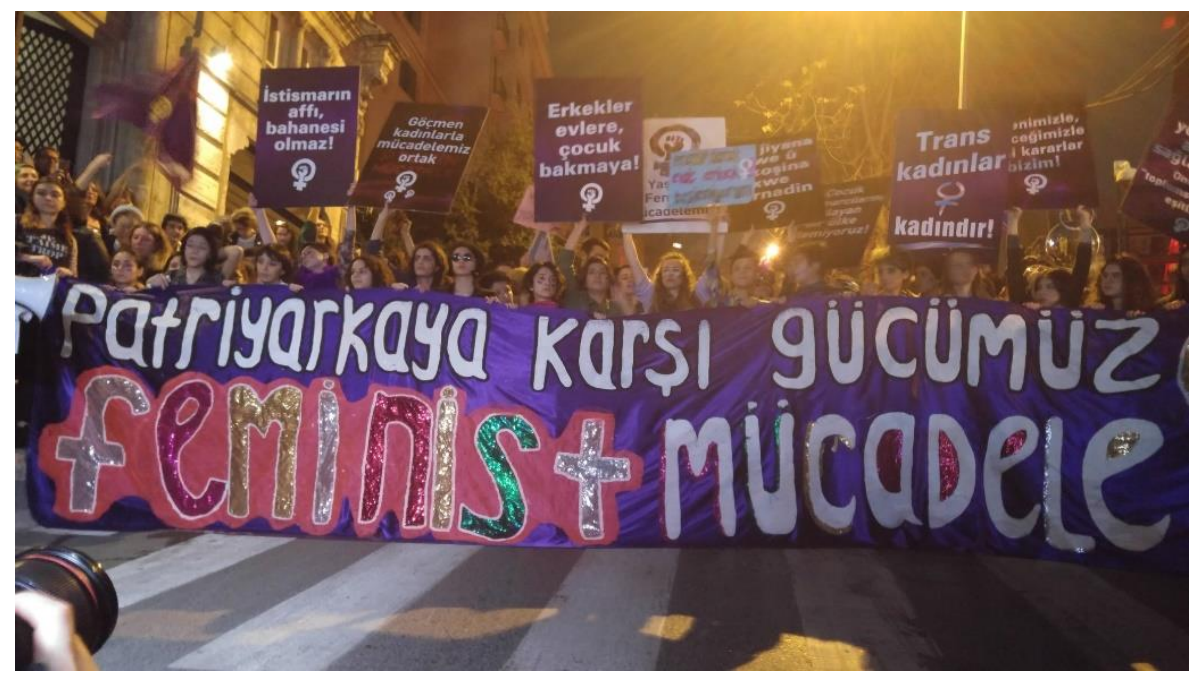

Şekil 1. “Erkekler evlere, çocuk bakmaya!" (Sayın, 2020)

İstanbul yürüyüşünde öne çıkan sloganlardan bazıları şunlardır; "Susmuyoruz, korkmuyoruz itaat etmiyoruz", "Erkekler evlere ütü yapmaya", "Kadın cinayetleri politiktir". Buradan hareket ile söylenebilir ki; kadınlar ataerkinin kendilerine dayattığı susma rolünün ayırdında ve karşısındadır. Özellikle erkekleri ücretsiz ev-içi emeğe davet ederek, gücün üretildiği kamusal alanın kendilerine bırakılmasını istemişlerdir. Burada, kadının yokluğunda şekillenen kamusal mekânda, tekrar tekrar üretilen neoliberal rejimlerin politik atmosferinin kadını ölüme götürdügünün altı çizilmiştir. 


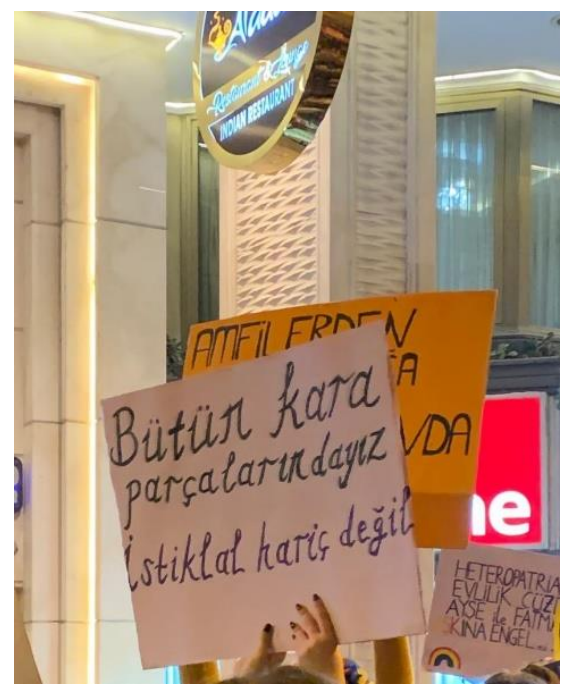

Şekil 2. "Bütün kara parçalarındayız istiklal hariç değil" (8 Mart Yürürüyüş̧, 2020)

Kadınlar "Bütün kara parçalarındayız, İstiklal hariç değil” pankartı ile alınan yasak kararını eleştirirken, tekrar mekânda var olmayı vurgularlar. Cemal Süreya tarafindan yazılmış Üvercinka şiirine atıfta bulunarak, bir anlamda edebiyat ile paralel, kadının kendini konumlandıracağı bir alan, karşı bir dil üretilebilmiştir. Benzer biçimde edebiyat üzerinden kadının hangi saatte olursa olsun kamusal alanda özgürce var olabileceğine dikkat çeken pankartlar da üretilmiş, kadına alternatif bir alan yaratmanın yolları aranmıştır.

Kadının kamusal alana dahil olma çabası 1970'lere kadar kadın doğasının reddi ile kamusal alan hâkimi erkekle eşitlenme fikri ile yürütülmüş; 1970'ler sonrası beden, kürtaj, doğurganlık gibi kavramların sorgusunun yükselmesi kadının kendi kimliği ile kamusal alana katılma çabasına dönüşmüştür (Göle ve C,ayır, 2000: 48-49). Bu kadını dişlayarak oluşmuş modern kamusal alanın da eleştirisini beraberinde getirir. Kadın kimliğine ait farklılıklar ve değişkenlikler ile kamusal alanda var olması ancak kamusal alan kavramının bu farklılıkları kabulü ile mümkündür. Bu bağlamda kadınlar yürüyüşte kendi söylemleri ile ataerki sınırları içerisinde tek tipleşen kadın kavramına, tüm sınıfsal farkındalığı ile kamusal alan hakkının ve ihtiyaçlarının çeşitliliğine de değinmişlerdir. 


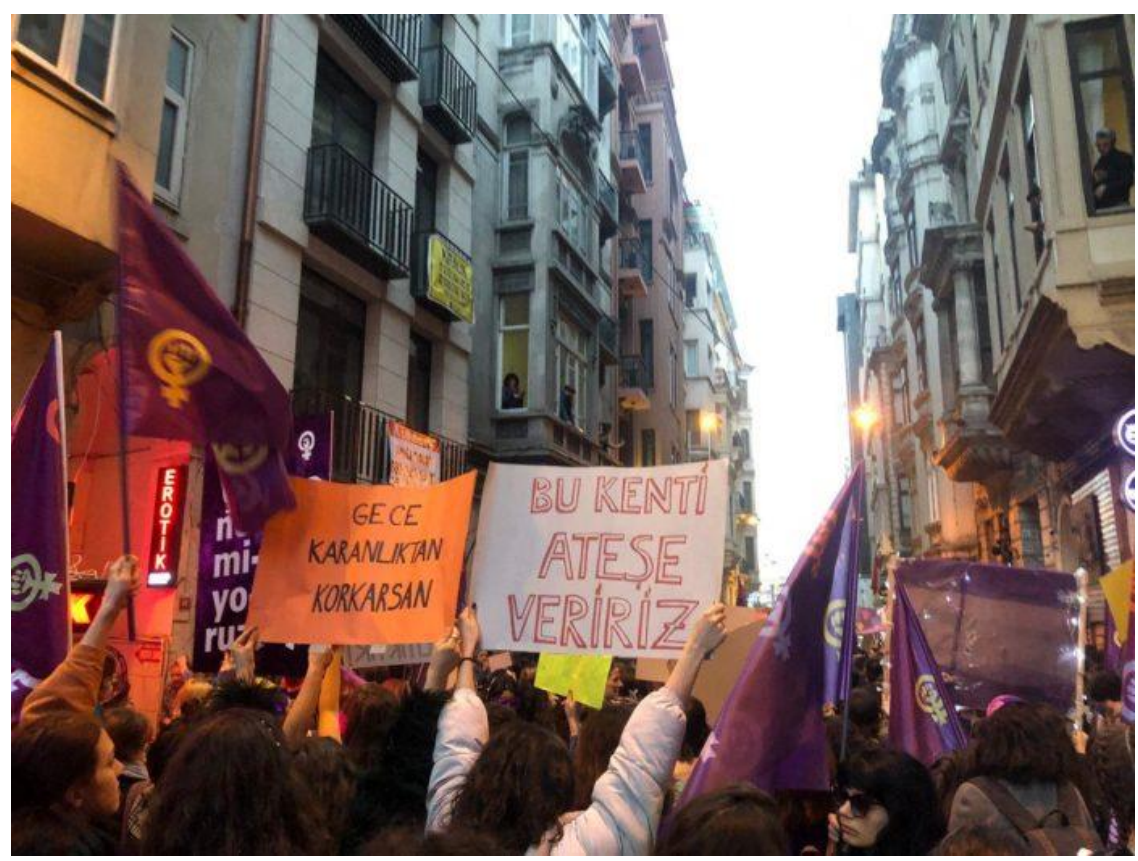

Şekil 3. Gece karanlıktan korkarsan, bu kenti ateşe veririrz

(Kadın Komiteleri, 2020)

Liz Bondi (1998)'ye göre; “Ayrı küreler ideali, aynı zamanda, kadınların 'erkeklerin' mekânlarındaki davranışları üzerinde de yankılanır; 'yabancı tehlike' tartışmalarından yola çıkarak, kadınların açık kentsel alan katılma hakkının erkeklerden daha az olduğuna işaret eder". Böylece bu ideal aynı zamanda kentin planlanmasında güçlü bir etki göstererek kadınların alan kullanımını sınırlamış ve kadınlık, mahremiyet ve özel alan arasındaki ilişkileri güçlendirmiştir. Şekil 3'deki pankart “Gece karanlıktan korkarsan, bu kenti ateşe veririz" diyerek kadının belli bir saatten sonra kent içinde elinden alınan hakkını, "yabancı tehlike" durumuna, kadınların günlük faaliyetlerinde engel oluşturan, kadınları neredeyse yürümeye, hareket etmeye ve şehrin belirli bölgelerinde kalmaya zorlayan bu duruma da atffta bulunarak arar. Kadınların hakkı olanı kararlılıkla savunacağına işaret ederken ataerkinin bütün kanallarına seslenmektedir. 


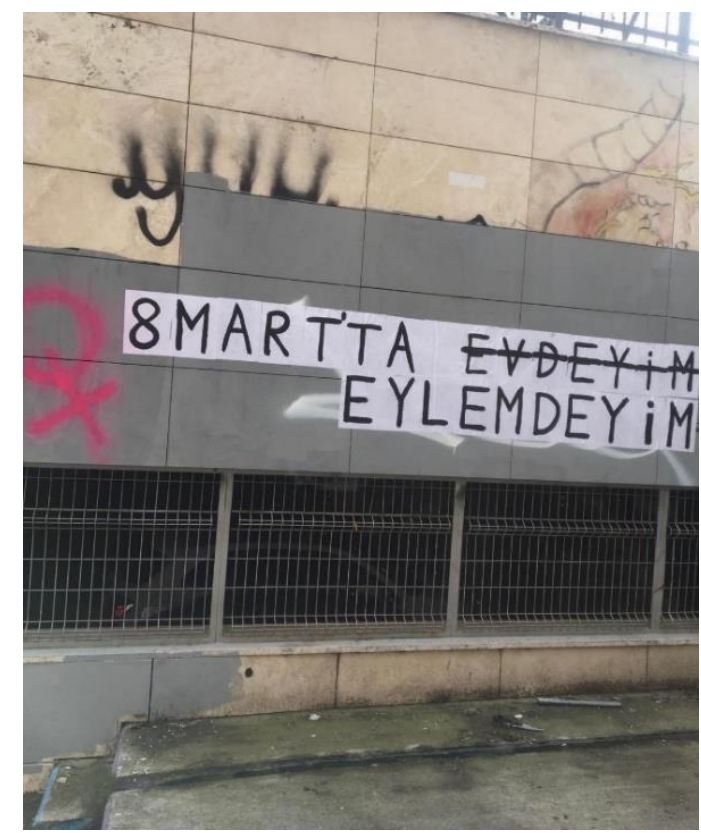

Şekil 4. “8 mart'ta evdeyim eylemdeyim.” (8 Mart Yürürüyüş, 2020)

Kadınlar, doğal olanla, aile ile bağımlı olanla, domestikle, samimiyetle, bakımla ve uysallık ile ilişkilendirildikleri özel alanı, evin gölgeli iç sınırlarını reddetmiş; soyut olanla, rasyonellikle, yönetimle, söz hakkıyla, ücretli emekle, kültürel olanla ve eylemle ilişkilendirilen kamusal alana, sokağa taşmiştır.

\section{Sonuç}

Bu çalışmanın amacı, mekân ve cinsiyet teorileri arasındaki söylemsel ilişkiyi anlamak olarak ifade edilebilir. Cinsiyet ve mekân teorilerinin kesişim noktasindan özellikle kamusal ve özel alan ayrımına odaklanarak teorik bir altyapı oluşturduktan sonra çalışma, 8 Mart özelinde kadınların söylediklerine odaklanarak kentsel bir ortamda cinsiyet-mekân ilişkisini kapsayan bir vaka çalışmasını araştırmıştır.

Mekân, 1960'ların devrimci döneminin başlangıcından bu yana hem sosyal hem de fen bilimleri için önemli bir tartışma olmuştur. Buna ek olarak; kimlik, aidiyet ve insanı anlamak adına daima başvurulan, eksiksiz bir bakış açısı sunar. Dolayısı ile coğrafyacıların, farklı bir mekân tasviri bulmak için çeşitli yerleşimleri ve ortamları araştırması sonucu mekânın anlamı ve mekân anlayışı giderek genişlemiştir. Kadın olmanın ardındaki anlamı ve erkeklerin 
toplumdaki hâkimiyetinin nedenlerini sormaya başlayan feminist coğrafyaclar böylece Lefebvre tarafından 1960'larda sosyal bir ürün olarak tanımlanan mekânı yeni bir araştırma alanı olarak kabul etmiş ve bu alanda çalışmalar üretmiştir. Bu çalışmaların bir sonucu olarak, pek çok çeşitli alandan akademisyen emek, göç, sınırlar, yer ve mekân gibi geniş bir yelpazedeki diğer konularla birlikte, kadınların kaygılarını dile getirmiştir. Bu çalışmalar dünyadaki yersiz ve yerinden edilmiş insanların sorununa kadınlara özel bir önem vererek değinmiştir. Feminist coğrafyacilar bu alanlardaki problemlerin üzerinde durarak, toplumsal cinsiyeti; toplumun katı kuralları ve değerleri tarafından kültürel olarak oluşturulmuş ve mekânsal olarak konumlandırılmış bir toplumsal performans olarak görmüştür. Böylece toplumsal cinsiyet ve mekân ilişkisi daima birbirlerinden etkilenen çift yönlü, dairesel bir konumda kabul edilmiştir. Mekânın üretimi sürecinde, dışlananın dâhil edilenler kadar önemli olduğu anlaşılmıştır. Hatta Foucault'cu bir yaklaşımla, güç ilişkilerindeki direnç dinamizmi nedeniyle daha da kritiktir. Bu anlamda toplumsal cinsiyet ve mekân arasındaki tartışmalar yoğun olarak kadınların kamusal alandaki yokluğu üzerinde durmuştur.

Kamusal ve özel mekân ayrımı, mekânsal olarak yeniden üretilse bile, güç ilişkileri, siyasi meseleler ve popüler söylemlerle var olur. Ayrı kürelerin ideolojisi, ataerkil kamusal üretim ve onun alt üretimi olan özel alandan oluşur ve bu alanları kadın ve erkekle ilişkilendirir. Bu anlamda ideoloji hem kapitalist hem de ataerkildir. Feminizmin bu konu ile yakın ve süregelen bağlantısı, bu ayrımın sürekli olarak yeniden üretilmesindedir. Kamusal/özel ayrımı tekrar tekrar çoğaltılarak, genellikle geleneksel ataerkil ve heteroseksist güç oluşumlarını koruyan cinsiyet ve cinsel farklılıkları oluşturmak, kontrol etmek, disiplin etmek, sınırlamak ve bastırmak için kullanılmaktadır. Aynı zamanda bu ayrım cinsiyetlerin her iki alanda nasıl davranması gerektiğini baskı ile belirler. Emeğin dağılımının sınırlarını çizerek, genellikle güç ilişkilerinin etkili bir parçası olmaktan mahrum bırakılmış olan kadınları özel alana ve eve sınırlandırarak kamusal alandan dışlar.

8 Mart kadın direnişinin sesini duyurduğu, baskın söylem içerisinde kendi bedeni, iradesi ve var oluşu üzerinde oluşturulan yapay rol ve görevlere direndiği bir gündür. Dolayısı ile pankart ve sloganlar süregelen kamusal alan ve özel alan ayrımının kadını baskılamak, sınırlamak adına üretilmiş yapılanmasına karşı, kadının temsil ve var oluşunun pratiğidir. Bu anlamda zaman zaman mizahi, zaman zaman edebi ve yer yer sert söylemlerin ironik, kararlı, isyankâr tonunun toplumsal algıları söylem aracıllğı ile yıkma girişimi olduğunu söylemek yanlış olmaz. Bu kamusal alanda üretilerek, özel 
alana taşan ve tersine de aynı düzlemde gelişen politik sınılamayı yıkmanın bir yoludur.

2020 yılında yapılan bu gösteri ve yürüyüşler göstermektedir ki, kadın kendisini kamusal alandan ve dolayısı ile güç tartışmalarından uzaklaştıran, onu evde ödemesiz bir emeğe hapseden, iş yaşamından geriye çeken ve cinsiyet eşitsizliğini körükleyen ataerkil anlayışın son derece ayırdında ve isyanındadır. Feminist kadınlar aynı zamanda, söyleyebilme eyleminin de sınısal olduğunun bilinci ile göçe, açlığa ve şiddete de değinmişlerdir. Ancak, pankartlardan da anlaşıldığı üzere, kamusal alanın ataerkil anlayışla erkeğe atfı 2020 yılında hala geçerli ve yıkılması gereken bir söylemdir.

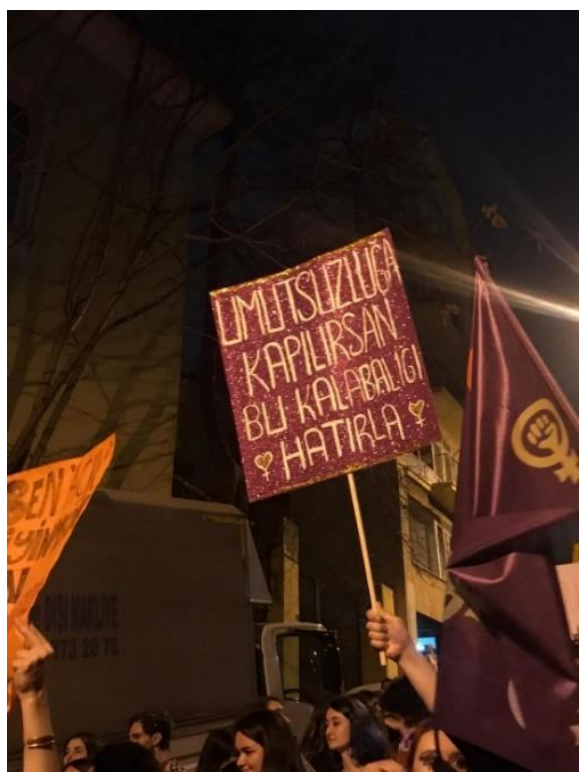

Şekil 5. “Umutsuzluğa kapilırsan bu kalabalığı hatırla.”

(Toplumsal Eşitlik Platformu, 2020)

Simone de Beuvoir (1989) erkeğin 'tarihsel bir idea' olduğunu söyler. Erkeklik tarih sayfalarında ince ince işlenirken, kadının varlık ve yetenekleri hiçe indirgenmiştir. Ataerkil düzenin ortaklığında üst üste konularak inşa edilen erkekliğin yenilmesi ancak kadının tüm kapasitesinin açığa çıkması ve fark edilmesi ile olacaktır. Tarih boyunca silinen kadın bugün tekrar tekrar, bu unutulmuş gerçekliğin ifadesi için uğraşmaktadır. Kadının kurtuluşu ve özgürlüğü yalnızca ve yalnızca kendisi tarafından görünürlükle sağlanabilir. Bu yüzden şehirde ve sokakta hak iddiası hala geçerli ve yerindedir. Kamusal alanda kadın varlığı, kendi söylemleri ile, gece yürüyüşleri ile daima yankılanacaktır. 


\title{
Extended Abstract
}

\section{Gender Discourse in the Public Sphere through the Voice of Women: 8 March celebrations in Turkey}

\author{
Nagehan Vanlığlu Yazıcı \\ ORCID: 0000-0001-5597-2278
}

The aim of this study can be expressed as understanding of the discursive relationship between space and gender theories. After establishing a theoretical background from the intersection of gender and spatial theories, this study investigates a case study that covers the gender-space relationship in an urban environment by focusing on women's slogans and banners on celebration of March 8th.

Space has been an important discussion topic for both social sciences and natural sciences since the beginning of the revolutionary period of the 1960s. In addition, it offers a complete perspective that is continually being used to understand identity, belonging, and human beings. Thus, the meaning and understanding of space have gradually expanded as a result of the geographers' search for various settlements and environments in order to find a different definition of space. Feminist geographers began to inquire about the meaning of being a woman and the reasons for men's dominance in society. Informed by Lefebvre's approach to space as a social product, they developed a new perspective for woman's existence in space which brought about a new field of research. As a result, scholars from a wide variety of fields have expressed women's concerns, together with a wide range of other topics such as labor, migration, borders, location, and space. These studies address the problem of misplaced and displaced people worldwide, with special attention being given to women. Feminist geographers accepted gender as a social performance that was culturally formed and spatially positioned by the strict rules and values of society, and they focused on the problems in these areas. Thus, the relationship between gender and space has always been accepted to be a bidirectional, circular one in which each is affected by the other. It has 
been understood that during the process of the production of space, that which is excluded is as important as that which is included. In fact, with a Foucauldian approach, these factors are even more critical because of the dynamism of resistance in power relations. In this sense, the debates between gender and space have focused heavily on the absence of women in the public sphere.

The distinction between public and private space exists through power relations, political issues, and popular discourses, even if reproduced spatially. The ideology of separate spheres consists of patriarchal production, which is public space and its sub production, which is private sphere; these spheres are related to men and women. In this sense, ideology is both capitalist and patriarchal. The close and enduring connection of feminism to this subject, stems from the constant reproduction of this distinction. The public/private distinction, by its repeated reproduction, is often used to create, control, discipline, limit, and suppress gender and sexual differences that preserve traditional patriarchal and heterosexist power formations. Simultaneously, this distinction dictates, by pressure, how the genders should behave in both areas. By drawing the boundaries of the distribution of labor, women, who have often been deprived of being an effective part of power relations are excluded from the public sphere by restricting them to the private sphere, i.e. home.

March 8th is the day when women's resistance makes its voice heard, and women resists the artificial roles and duties created within the dominant discourse by society on women's will, their existence, and their own bodies. Therefore, banners and slogans are the practice of the representation and existence of women against the ongoing structure of the separation between public and private spheres, created to suppress and limit women.

In this sense, it would not be wrong to say that the ironic, decisive, rebellious tone of humorous, sometimes literary and sometimes harsh discourses are an attempt to destroy social perceptions through discourse. This is a way of breaking through the political constraint that is produced in the public sphere, that spills over into the private sphere and, conversely, develops on the same plane.

These demonstrations and marches held in 2020 show that women are extremely aware of, and rebellious towards, the patriarchal understanding that distances women from the public sphere and, consequently, from power debates, imprisons them in unpaid labor at home, withdraws them from business life, and fuels gender inequality. Feminist women also touched upon migration, hunger, and violence with the awareness that the act of being able to 
speak is also depends on class. However, as can be understood from the banners, the reference of the public sphere to men with a patriarchal approach is still valid in 2020 and is a discourse that needs to be destroyed.

The defeat of masculinity, which is built on top of each other in the partnership of the patriarchal order, will only be possible when the full capacity of women is revealed and realized. The woman, who has been erased throughout history, today still struggling, again and again to express this forgotten reality. Women's emancipation and freedom can only be achieved through visibility, and only by themselves. Therefore, their claims in the city and on the streets are still valid and right. The presence of women in the public sphere will resonate constantly with their own discourses, and with the night walks.

\section{Kaynakça/References}

@8MartYuruyus. (2020, March 8). 8 Mart Yürüyüş [Digital image]. Retrieved 2020 from https://twitter.com/8MartYuruyus/status/1236635456323883009/photo/1

Agrest, D. (1991). Architecture from without: Theoretical framings for a critical practice. Cambridge, MA: MIT Press.

Arat, Y. (1993). Women's Studies in Turkey: From Kemalism to Feminism. New Perspectives on Turkey, 9, 119-135.

Arendt, H. (2012). İnsanlık durumu. Çev. Bahadır Sina Şener, İstanbul: İletişim.

Barbara, P. Rendell, J. ve Borden, I. (2000). Gender space architecture: An interdisciplinary introduction. London: Routledge.

Basa, İ (2018). Ödünç kentsel mekânlar: bir meydan çözümlemesi: Viyana Belediye Meydanı (Wiener Rathausplatz). İdealkent - Kent Araștrmaları Dergisi, 23, 236-257.

Basa, İ. (2016). Söylemsel zapturapt: Kamusal mekân eli (/dili) ile kentsel kültürü ehlileştirmek, Arredamento Mimarlk, 301, 96-101.

Bondi, L. (1998). Gender, class, and urban space: Public and private space in contemporary urban landscapes. Urban Geography, 19(2), 160-185.

Bondi, L., Davidson, J. (2003). Troubling the place of gender. K. Anderson, M.Domosh, S.Pile, N. Thrift. (Eds.). Handbook of cultural geography. Içinde (s.325-343). Sage yay.

Butler, J. (1988). Performative acts and gender constitution: An essay in phenomenology and feminist theory. Theatre Journal, 40(4), 519-531.

Çoban, F. (2017). Toplumsal cinsiyet kuramına giden yolda yaşamı ve fikri katkılarıyla Clara Zetkin. Journal of Social Sciences, X(1), 98-127.

De Beauvoir, S. (1989).The second sex. Ed. H. M. Parshley. South Yarra, Vic.: Louis Braille Productions.

Doğanay, G. (2018). Siyaset alanını arındırma: Hannah Arendt'i yeniden düşünmek. Dokuz Eylül Üniversitesi Sosyal Bilimler Enstitüsü Dergisi, 20 (2), 211-231.

Duncan, N. (1996). Bodyspace: destabilizing geographies of gender and sexuality. Psychology Press.

Foucault, M. (1972). Archeology of knowledge. New York, U.S.A. Pantheon Books. 
Göle, N., Çayır, K. (2000). İslam'ın yeni kamusal yüzleri: İslam ve kamusal alan üzerine bir atölye çalışması. İstanbul: Metis Yayınları.

Harvey, D. (2008) The Condition of post-modernity: An enquiry into the origins of cultural change. Cambridge: Wiley-Blackwell.

komiter.org. (2020, March 12). Kadın Komiteleri, [Digital image]. Retrieved 2020, from http://komiteler.org/2020/03/gece-karanliktan-korkarsan-bu-kenti-atese-veririzkadin-komiteleri/

Kandi:yoti, D. A. (1987). Emancipated but unliberated? Reflections on the Turkish case. Feminist Studies, 13(2), 320.

Kara, N. (2006). Feminist movements in Turkey at 80 and 90s /80 ve 90'larda Türkiye'de feminist hareketler. Women's Studies Journal, 3, 16-39.

Karagöz, B. (2008). Türkiye'de 1980 sonrası kadın hareketinin siyasal temelleri ve "İkinci Dalga" urağı. Memleket, 3(7), 168-190.

Kuriş, Z. (2015). Türkiye kadın hareketi: Sözden, eyleme, eylemden çoğulculuğa Aksu Bora. Başlangıç. https://baslangicdergi.org/turkiye-kadin-hareketi-sozdeneyleme-eylemdencogulculuga-1/, (accessed, January, 2020).

Lazar, M. (2007). Feminist critical discourse analysis: Gender, power and ideology in discourse. New York: Palgrave Macmillan.

Lefebvre, H. (1991). The production of space. Oxford, OX, UK: Blackwell.

McDowell, L. (1992). Doing gender: Feminism, feminists and research methods in human geography. Transactions of the Institute of British Geographers, 17(4), 399-416.

McDowell, L. (1993). Space, place and gender relations: Part I. Feminist empiricism and the geography of social relations. Progress in Human Geography. 17(2), 157-179.

Mimarlar Odası İstanbul Büyükkent Şubesi. (2013). Kent, Kültür, Çevre, Mimarlık ve Demokrasi İçin Mimarlara Mektup. İstanbul.

Mirioğlu, G. (2018). Kentlere feminist coğrafya perspektifinden bakmak (Looking to the cities through a perspective of feminist geography). Ege Coğrafya Dergisi, 27 (2), 183-194.

Sayın, F. (2020, March 9). @FerdaHepa [Digital image]. Retrieved 2020, from https://twitter.com/FerdaHepa/status/1236783441070493697

Shields, R. (1999). Lefebvre, love, and struggle: Spatial dialectics. London, England: Routledge.

Soja, E. (1989). Postmodern geographies. London: Verso.

@teplatformu. (2020, March 8). Toplumsal Eşitlik Platformu. [Digital image]. Retrieved 2020, from https://twitter.com/TEPlatformu/status/1236717900997820419/photo/1

Vanlığlu Yazıcı, N. (2019). Gender discourse and public space: Socio-spatial construction of gender in the city, the case of Rize, Turkey. Yayımlanmamıs Yüksek Lisans Tezi. ODTÜ, Ankara 